\title{
Native Low Density Lipoprotein-induced Calcium Transients Trigger VCAM-1 and E-selectin Expression in Cultured Human Vascular Endothelial Cells
}

\author{
Sean Allen, Shabeena Khan, Futwan-Al-Mohanna, ${ }^{*}$ Puspa Batten, and Magdi Yacoub \\ Department of Cardiothoracic Surgery, Imperial College of Science, Technology and Medicine, Harefield Hospital, Harefield, Middlesex, \\ UB9 6JH United Kingdom; and * King Faisal Specialist Hospital and Research Centre, Riyadh, Saudi Arabia
}

\begin{abstract}
Low density lipoprotein (LDL) interactions with the endothelium are thought to play a major role in the development of atherosclerosis. The mechanism(s) involved are not fully understood, although several lines of evidence support the idea that oxidation of LDL increases its atherogenicity. In this study we report for the first time that native LDL (n-LDL) binding to the $\mathrm{LDL}$ receptor $(100-700 \mu \mathrm{g} / \mathrm{ml})$ triggers a rise in intracellular calcium which acts as a second messenger to induce vascular cell adhesion molecule-1 (VCAM-1) expression in human coronary artery (HCAEC) and pig aortic endothelial cells (PAEC) and VCAM-1 and E-selectin expression in human aortic (HAEC) endothelial cells. Preincubation of HCAEC with a monoclonal antibody (IgGC7) to the classical LDL receptor or pretreatment with pertussis toxin blocked the n-LDL-induced calcium transients. Preincubation of each of the endothelial cell lines with the calcium chelator 1,-2-bis(o-aminophenoxy)ethane- $N, N, N^{\prime}, N^{\prime}$ tetraacetic acetomethyl ester (BAPTA/AM) prevented the expression of VCAM-1 and E-selectin. The increase in VCAM- 1 by $n-L D L$ results in increased monocyte binding to HCAEC which can be attenuated by inhibiting the intracellular calcium rise or by blocking the VCAM-1 binding sites. These studies in human and pig endothelial cells link calcium signaling conferred by n-LDL to mechanisms controlling the expression of endothelial cell adhesion molecules involved in atherogenesis. (J. Clin. Invest. 1998. 101: 1064-1075.) Key words: n-LDL • selectins • integrins • signaling • endothelium
\end{abstract}

\section{Introduction}

It is recognized increasingly that development of atherogenesis is a complex and multifactorial disease that depends on the exchange of messages by resident cells (endothelial and smooth muscle cells) and infiltrating leukocytes that regulate functions critical to lesion initiation and progression and to clinical manifestations of coronary artery disease. LDL interaction with

Address correspondence to Professor Sir Magdi H. Yacoub FRCS, Department of Cardiothoracic Surgery, Imperial College of Science, Technology and Medicine, Heart Science Centre, Harefield Hospital, Hill End Road, Harefield, Middlesex, UB9 6JH, UK. Phone: 44-1895828893; FAX: 44-1895-828902.

Received for publication 21 April 1997 and accepted in revised form 30 December 1997.

J. Clin. Invest.

(C) The American Society for Clinical Investigation, Inc. 0021-9738/98/03/1064/12 \$2.00

Volume 101, Number 5, March 1998, 1064-1075

http://www.jci.org the intimal layer of large arteries seems to be one of a number of factors critical to lesion development. There is an increased risk for complications of atherosclerosis when plasma LDLcholesterol is increased (1) and many clinical trials document that pharmacological treatment of coronary-prone patients with lipid lowering agents can reduce coronary events and total mortality $(2,3)$.

An important early event in the initiation of atherosclerosis is the increased uptake of monocytes into the intima where they differentiate into macrophages (4) and ingest modified forms of LDL to become foamy macrophages (5-7) which give rise to "fatty streaks," the precursor lesion which subsequently leads to development of atherosclerosis. Consequently, much attention is now focused on understanding the etiology of the fatty streak and the mechanisms by which LDL can affect components of the atherosclerotic process. Monocyte recruitment into the vessel wall is a complex process that includes cell rolling, firm attachment, and directed migration. Movement of monocytes into the intima can be dissected into distinct but continuous stages involving sequential interactions of different molecules on the monocyte and endothelial cell surface. Evidence supporting an important role of oxidative modification of LDL in influencing all stages of monocyte binding to the vessel wall is growing (8). For example, treatment of endothelial cells with oxidized LDL increases P-selectin $(9,10)$ and vascular cell adhesion molecule (VCAM-1) ${ }^{1}$ (11) expression, as well as inducing endothelial cells to produce potent monocyte activators, monocyte chemoattractant protein-1 (12), and monocyte colony stimulating factor (13). However, much less is known about the cellular and molecular mechanisms by which native LDL (n-LDL) activates endothelial cells to influence atherogenesis. Endothelial cell activation is pivotal in driving cell adhesion and migration. One of the earliest signs of endothelial cell activation is a rise in intracellular calcium. Several lines of evidence have suggested that calcium may be involved in atherogenesis. First, a fivefold increase in intracellular calcium in aortic endothelial cells of cholesterol-fed rabbits has been observed compared with normal rabbits (14). Secondly, several groups have shown that calcium antagonists have an antiatherogenic effect in animals fed a diet rich in cholesterol (15). Thirdly, increases in calcium have been shown in a limited number of endothelial cells including human umbilical vein (16), bovine (17), and the endothelial cell line

1. Abbreviations used in this paper: BAPTA/AM, 1,-2-bis(o-aminophenoxy)ethane- $N, N, N^{\prime}, N^{\prime}$-tetraacetic acetomethyl ester; BHT, butylated hydroxytoluene; Br-A23187, bromo-calcium ionophore; Fura-2/AM, Fura-2 acetomethyl ester; H-7, 1-[5-isoquinolinesulfonyl]-2-methyl-piperazine; HAEC, human aortic endothelial cells; HCAEC, human coronary artery endothelial cells; n-LDL, native LDL; PAEC, pig aortic endothelial cells; PKC, protein kinase C; TPEN, $N, N, N^{\prime}, N^{\prime}$-tetrakis(2-pyridylmethyl)ethylenediamine; VCAM-1, vascular cell adhesion molecule-1. 
EA.hy926 (18) after the addition of LDL. Finally, endothelial cell injury either induced by high plasma cholesterol levels or by other conditions is causally related to an increase of the calcium content in the atheromatous area (19). Therefore, if calcium is an important mediator in atherogenesis and lipoproteins also have an important role, it is possible that the effects of these lipoproteins and cellular calcium homeostasis are interrelated.

In this study we report the novel finding that n-LDL binding to the LDL receptor can trigger intraendothelial cell calcium transients which act as a second messenger to induce VCAM-1 and E-selectin expression in human vascular endothelial cells and VCAM-1 in porcine vascular endothelial cells. The increase in VCAM-1 by n-LDL results in increased monocyte binding to human coronary artery endothelial cells (HCAEC). These results link calcium signaling conferred by $\mathrm{n}$-LDL to mechanisms controlling the expression of endothelial cell adhesion molecules involved in atherosclerosis.

\section{Methods}

\section{Materials}

LDL, VLDL, HDL, pertussis toxin, 1-[5-isoquinolinesulfonyl]-2-methylpiperazine (H-7), $N, N, N^{\prime}, N^{\prime}$-tetrakis(2-pyridylmethyl)ethylenediamine (TPEN), butylated hydroxytoluene (BHT), and PMA were purchased from Sigma Chemical Co. (Dorset, UK). Fura-2 acetoxymethyl ester (Fura-2/AM), thapsigargin, bromo-calcium ionophore (Br-A23187) and 1,-2-bis(o-aminophenoxy)ethane- $N, N, N^{\prime}, N^{\prime}$-tetraacetic acetomethyl ester (BAPTA/AM) were from Molecular Probes (Eugene, OR). Nycoprep was purchased from Nycomed (Oslo, Norway). The human VCAM-1 (clone BBA 6) and E-selectin (clone BBA 2) antibodies were purchased from R\&D Systems (Oxford, UK) and the mouse anti-human P-selectin antibody (CD62/GMP140, clone AC1.2) was purchased from Becton Dickinson, (Oxford, UK). Dil-Ac-LDL was purchased from Biogenesis (Bournemouth, UK). The mouse antihuman E-selectin (clone 1.2B6) and the mouse anti-human VCAM-1 (clone 1.4C7) antibodies were a kind gift from Professor D. Haskard (RPMS, Hammersmith Hospital, London, UK). R-phycoerythrin goat anti-mouse antibody and the mouse anti-human platelet-endothelial cell adhesion molecule-1 (CD31) antibody were purchased from DAKO Ltd. (High Wycombe, UK). Endothelial serum-free growth medium and medium 199 were purchased from GIBCO BRL (Paisley, UK). All other reagents were analar grade and purchased from BDH Chemicals (Poole, UK). The Fura-2/AM, thapsigargin, and $\mathrm{Br}-\mathrm{A} 23187$ were dissolved in DMSO and delivered to the cells at a final concentration of $1 \mu \mathrm{M}, 10 \mu \mathrm{g} / \mathrm{ml}$, and $2 \mu \mathrm{M}$, respectively, with a final DMSO concentration of $<0.1 \%$.

\section{Cell culture}

HCAEC and human aortic endothelial cells (HAEC) were isolated from vessels taken from recipient hearts obtained at the time of transplantation and cultured as described previously (20). Informed consent was obtained from each patient and the study was approved by the Harefield Hospital Ethical Committee. The cells were incubated at $37^{\circ} \mathrm{C}$, were grown into a confluent monolayer, were removed by trypsin/EDTA solution, and seeded into larger flasks for propagation. Cells were used between the third and tenth passage. Pig aortic endothelial cells (PAEC) were isolated as described previously (21), and serially cultured in endothelial cell serum-free growth medium supplemented with $150 \mathrm{U} / \mathrm{ml}$ penicillin, $150 \mathrm{U} / \mathrm{ml}$ streptomycin, and $2 \mathrm{mM}$ L-glutamine. All endothelial cell lines were used between the third and tenth passage.

Purity of the endothelial cells was assessed by positive staining for platelet-endothelial cell adhesion molecule-1 and Dil-Ac-LDL and negative staining for smooth muscle $\alpha$-actin. Human coronary artery and aortic endothelial cells were used because these cells provide an ideal model to study the effects of lipoproteins with blood vessels commonly affected by atherosclerosis. Furthermore, human transplanted hearts normally develop a severe form of accelerated coronary artery disease in which lipoproteins may also play a role. In this context, PAEC were used because of the interest in transplanting pig hearts into humans (xenotransplantation). In most cases, comparisons of the different cell types were performed in parallel on the same day.

\section{Preparation of lipoproteins}

n-LDL, VLDL, and HDL purchased from Sigma Chemical Co. were isolated sequentially from plasma by using the modified methods of Rudel et al. (22) and Rubenstein et al. (23). Each lipoprotein was concentrated and dialyzed extensively against $0.15 \mathrm{M} \mathrm{NaCl}, 0.01 \%$ EDTA, pH 7.4-7.5. The n-LDL and HDL were then filtered through a $0.2-\mu \mathrm{m}$ membrane and VLDL was filtered through a $0.45-\mu \mathrm{m}$ membrane. Each lipoprotein class was then checked for its characteristic electrophoretic and chemical composition. The lipoproteins were essentially free from contamination by other lipoproteins as determined by cellulose acetate electrophoresis using fat red 7B staining for lipid. We have also used freshly isolated n-LDL to compare with $\mathrm{n}$-LDL obtained from Sigma Chemical Co. in our system. The fresh samples of n-LDL (three human volunteers) were also isolated by the methods outlined above and were a kind gift from Dr. Dilip Patel (MRC Lipoprotein Group, Hammersmith Hospital, London, UK) and Dr. Richard Siow (Vascular Biology Research Centre, King's College, London, UK). Dr. David Leake (School of Animal and Microbial Sciences, University of Reading, Reading, UK) also provided us with samples of minimally modified and oxidized LDL. Each lipoprotein was stored at $2-8^{\circ} \mathrm{C}$ and used within 2 wk.

\section{Calcium measurements}

The HCAEC and PAEC plated on glass coverslips at $10^{5}$ cells $/ \mathrm{ml} 18$ $24 \mathrm{~h}$ previously were loaded with Fura-2/AM $(1 \mu \mathrm{M}$ for $30 \mathrm{~min}$ at room temperature) in Krebs-Hepes medium ( $\mathrm{pH}$ 7.4) containing $120 \mathrm{mM} \mathrm{NaCl}, 1.3 \mathrm{mM} \mathrm{CaCl}_{2}, 1.2 \mathrm{mM} \mathrm{MgSO}_{4}, 4.8 \mathrm{mM} \mathrm{KCl}, 1.2 \mathrm{mM}$ $\mathrm{KH}_{2} \mathrm{PO}_{4}, 25 \mathrm{mM}$ Hepes, $25 \mathrm{mM}$ glucose, and $0.1 \%$ bovine serum albumin. The cells were then washed twice with Krebs-Hepes and left for a further 15 min to allow complete hydrolysis of the Fura-2 ester.

In experiments involving pharmacological agents, endothelial cells were preincubated for a given time and temperature (as described) with the agent before the endothelial cells were loaded with Fura-2/AM. The coverslips were then secured between two plates of a 3-ml volume coverslip holder and mounted in a temperature-controlled incubation holder $\left(34^{\circ} \mathrm{C}\right)$ and placed onto a microscope stage of a Nikon Diaphot 200 inverted epifluorescence microscope. Intracellular calcium measurements were performed on individual cells using an ionVision dual excitation system (ImproVision, Coventry, UK). Absolute calcium levels were calculated as described previously $(20,24)$.

\section{Flow cytometry analysis}

Changes in VCAM-1 and E-selectin protein in control (TNF- $\alpha, 10$ $\mathrm{ng} / \mathrm{ml}$ ) and $\mathrm{n}$-LDL-treated endothelial cell cultures were determined using a flow cytometer. Endothelial cells were passaged into 24-well plates, brought to confluence, transferred to serum-free medium for $24 \mathrm{~h}$, and preincubated with n-LDL $(100,300,500$, and $700 \mu \mathrm{g} / \mathrm{ml})$ or normal cell culture media for $5 \mathrm{~min}, 30 \mathrm{~min}, 5 \mathrm{~h}$, and $12 \mathrm{~h}$. Viability of the cells was determined by microscopic evaluation and by trypan blue exclusion; the viability of the cells was $>90 \%$ after the incubation period. To be sure that any changes occurring were not due to mild oxidation of the n-LDL in culture, in some experiments we added BHT $(20 \mu \mathrm{mol} / \mathrm{liter})$ to the $\mathrm{n}-\mathrm{LDL}$ as this is known to eliminate nonspecific oxidation of the n-LDL particles during endothelial cell culture experiments $(25,26)$. In experiments to investigate whether n-LDL-induced changes in intracellular calcium correlate with adhesion molecule expression, endothelial cells were preincubated with the intracellular calcium chelator BAPTA/AM $(10 \mu \mathrm{M} ; 30$ 
min). Because BAPTA/AM is a chelator not only for calcium but also for other multivalent metal cations, some endothelial cells were preincubated with TPEN $(1 \mu \mathrm{M} ; 30 \mathrm{~min})$, a metal ion chelator that shows a marked preference for binding heavy metal cations over calcium, as a control for heavy metal scavenging by BAPTA/AM. At the end of each n-LDL incubation time the cells were washed, after which time TNF- $\alpha(10 \mathrm{ng} / \mathrm{ml})$ was added to control wells (no n-LDL treatment) and then left for a further $5 \mathrm{~h}$ before the cells were trypsinized and assayed for adhesion molecule expression. Expression of cell-surface molecules was measured as fluorescence intensity (EPICS XL-MCL

\section{A}
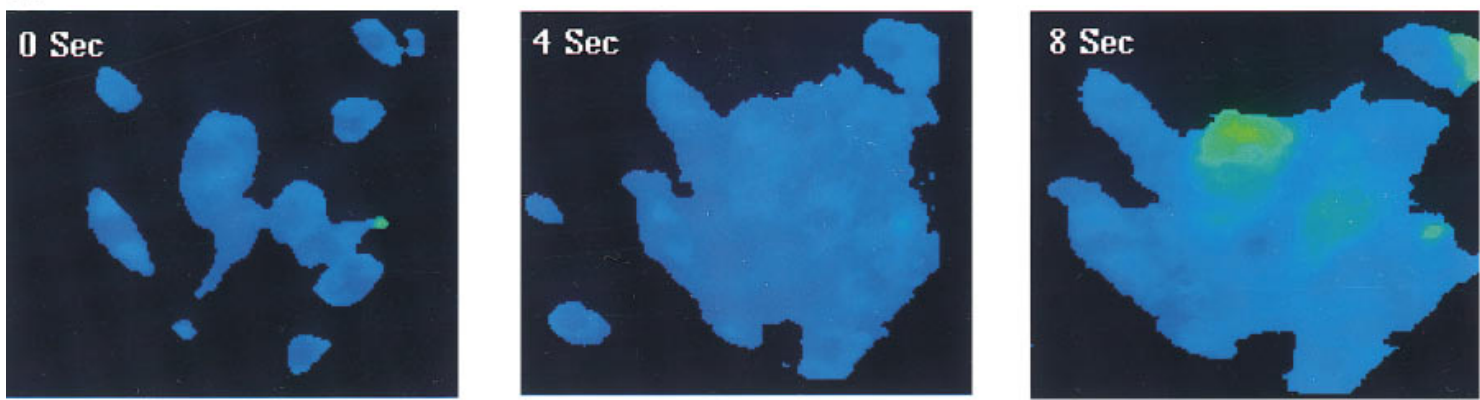

\section{$600 \mathrm{nM}$}
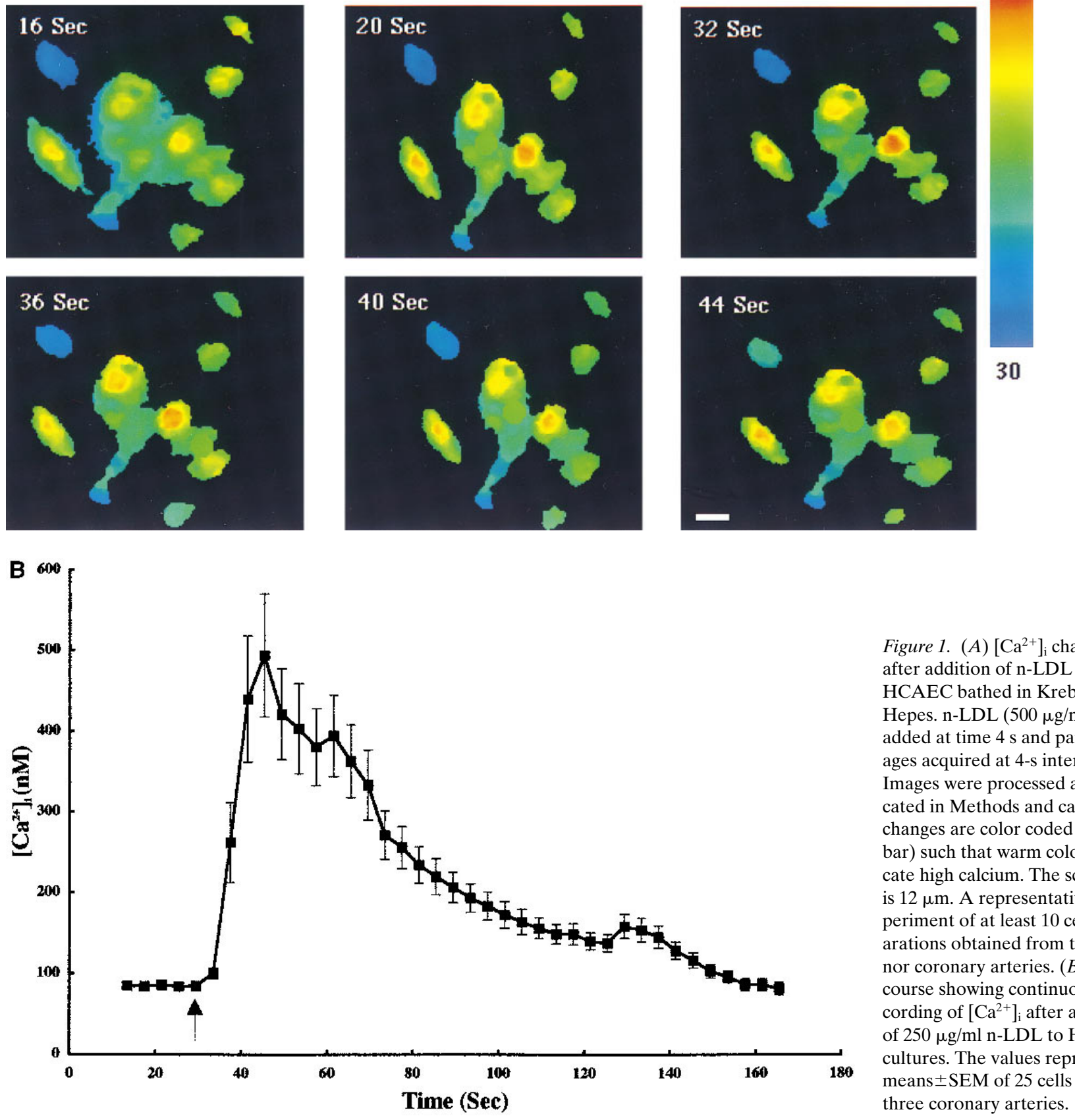

Figure 1. (A) $\left[\mathrm{Ca}^{2+}\right]_{\mathrm{i}}$ changes after addition of $n-L D L$ to HCAEC bathed in KrebsHepes. n-LDL $(500 \mu \mathrm{g} / \mathrm{ml})$ added at time $4 \mathrm{~s}$ and paired images acquired at 4-s intervals. Images were processed as indicated in Methods and calcium changes are color coded (color bar) such that warm colors indicate high calcium. The scale bar is $12 \mu \mathrm{m}$. A representative experiment of at least 10 cell preparations obtained from three donor coronary arteries. $(B)$ Time course showing continuous recording of $\left[\mathrm{Ca}^{2+}\right]_{\mathrm{i}}$ after addition of $250 \mu \mathrm{g} / \mathrm{ml} \mathrm{n}$-LDL to HCAEC cultures. The values represent means \pm SEM of 25 cells from three coronary arteries. 
flow cytometer; Coulter Corp., Miami, FL). Each sample counted $5 \times$ $10^{3}$ cells. Controls for each assay included the absence of the primary antibody and in some cases incubation of cells with BHT, TPEN, or an isotype-matched, irrelevant antibody.

\section{Immunofluorescence}

n-LDL $(500 \mu \mathrm{g} / \mathrm{ml})$ or Br-ionophore $(2 \mu \mathrm{M})$ was added to PAEC grown on glass coverslips $12-18 \mathrm{~h}$ previously. Coverslips were washed after $5 \mathrm{~min}$ and fixed in $3.7 \%$ (vol/vol) formaldehyde. P-selectin was visualized by indirect immunofluorescence using a monoclonal antiP-selectin antibody (CD62/GMP140, clone AC1.2) and TRITC-conjugated secondary antibody (Pierce, Rockford, IL). Cells were viewed with a laser-scanning confocal microscope (Noran Instruments, Milton Keynes, UK).

\section{Cell adhesion assay}

Isolation of monocytes. From each subject, $60 \mathrm{ml}$ blood was obtained from a forearm vein under fasting conditions and placed into a heparinized syringe containing sodium citrate at a final concentration of $\sim 20-50 \mathrm{IU} / \mathrm{ml}$. The blood was then mixed with $6 \%$ (wt $/ \mathrm{vol})$ dextran 500 in $0.9 \%$ saline and allowed to settle for $30-60 \mathrm{~min}$. The plasma was then layered onto Nycoprep (Nycomed) and monocytes were obtained according to the manufacturer's directions. The purity of the monocyte preparations was $>90 \%$ by FACS $^{\circledR}$ using the monocyte specific marker CD14, and cell viability as determined by trypan blue staining was $>95 \%$. Monocytes were then stained with the green fluorescent dye PKH2 (Sigma Chemical Co.) according to the manufacturer's instructions before addition to endothelial cell monolayers.

Adhesion of monocytes to HCAEC. Experiments were carried out in 24-well plates as a modification of the method described previously (27). Briefly, HCAEC were seeded in the medium and incubated at $37^{\circ} \mathrm{C}$ for $2 \mathrm{~d}$ until cells were confluent. The medium was then changed to serum-free medium and the cells were left for another $24 \mathrm{~h}$. At the end of this time $\mathrm{n}-\mathrm{LDL}(500 \mu \mathrm{g} / \mathrm{ml}$ for $5 \mathrm{~h})$ or TNF- $\alpha(10 \mathrm{ng} / \mathrm{ml}$ for $5 \mathrm{~h}$ ) was added to the medium bathing the cells. In some wells, cells were preincubated with BAPTA/AM $(10 \mu \mathrm{M}$ for $30 \mathrm{~min})$ before the addition of the n-LDL. At the end of the 5-h incubation, some cells were treated with an anti-VCAM-1 antibody (clone BBA 6, 30 min). All cells were then washed to remove unhydrolyzed BAPTA/ AM or unbound antibody before fluorescently labeled monocytes were added at a concentration of $10^{6}$ cells/well for $1 \mathrm{~h}$ at $37^{\circ} \mathrm{C}$. After the cells were washed several times, the adherent monocytes were counted in each well under a microscope using FITC illumination. For each measurement three wells were analyzed and five different fields of view were counted in each well. The various treatments in each well were unknown to the investigator.

\section{Statistical analysis}

Statistical analysis was carried using the commercial program Unistat version 4 for Windows (Unistat Ltd., UK). The results are expressed as mean \pm SEM. Calcium measurements were analyzed by either an unpaired Student's $t$ test or ANOVA coupled with a post-hoc Bonferroni correction analysis when appropriate. Adhesion molecule data were analyzed using repeated measures ANOVA. Differences were considered to be significant when the probability value was $<0.05$.

\section{Results}

Effect of $n-L D L$ on intracellular calcium. Addition of n-LDL (500 $\mu \mathrm{g} / \mathrm{ml})$ to HCAEC adherent to glass coverslips and bathed in Krebs-Hepes buffer caused a transient calcium rise from a resting level of $82 \pm 1.6$ to $610 \pm 135 \mathrm{nM}$ (mean \pm SEM, $n=35)$ (Fig. $1 A$ ). The average rise in intracellular calcium in HCAEC $(492 \pm 75 \mathrm{nM})$ reached a maximum $16 \mathrm{~s}$ after addition of $n-L D L$, followed by a gradual fall in intracellular calcium levels, returning to near baseline calcium levels by $160 \mathrm{~s}$ (Fig. 1 $B$ ). Compared with the reference standard thrombin, which

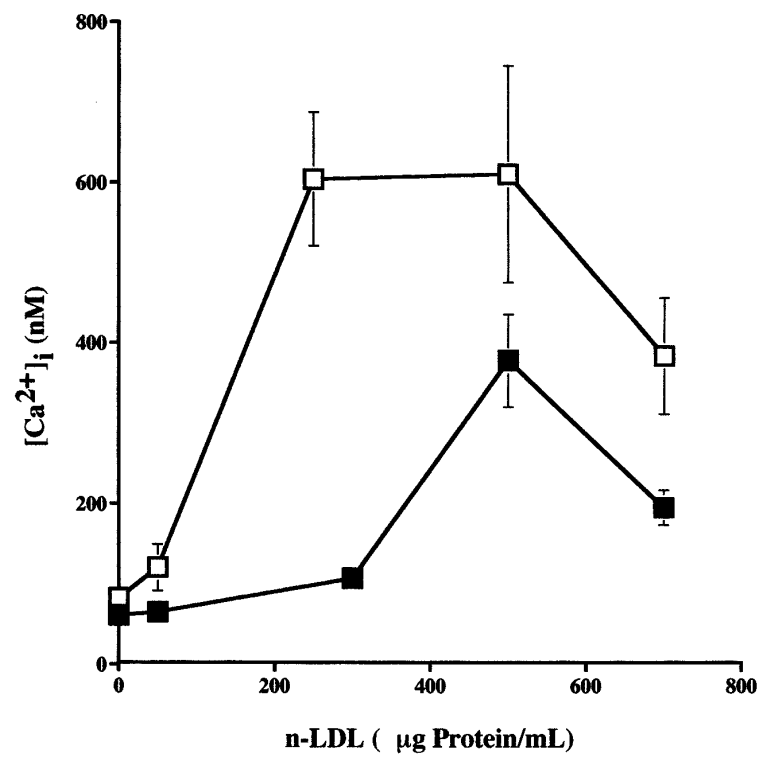

Figure 2. Concentration-dependent effect of n-LDL added to HCAEC (open boxes) and PAEC (filled boxes) on $\left[\mathrm{Ca}^{2+}\right]_{\mathrm{i}}$. The values represent means \pm SEM of 50 individual HCAEC obtained from three donor coronary arteries and 70 PAEC obtained from six donor aortae.

induced a calcium rise of $700 \pm 25 \mathrm{nM}(n=29)$, the average $\mathrm{n}$-LDL-induced calcium rise approximated to $70 \%$ of this response. Fresh n-LDL $(200 \mu \mathrm{g} / \mathrm{ml})$ also induced a calcium rise in HCAEC from a resting level of $79 \pm 2$ to $355 \pm 58 \mathrm{nM}$ (mean \pm SEM, $n=34$ ). There were no apparent differences in the magnitude or time course of the calcium transients when compared with the n-LDL samples obtained from Sigma Chemical Co. (data not shown). Similar observations were made in PAEC exposed to n-LDL $(500 \mu \mathrm{g} / \mathrm{ml})$ with the calcium level rising from a resting level of $76 \pm 1.0$ to $255 \pm 46 \mathrm{nM}$ (mean \pm SEM, $n=40$ ). The calcium transients in HCAEC and PAEC were dependent on the concentration of n-LDL and were saturable, and the half-maximally effective concentration $\left(\mathrm{EC}_{50}\right)$ was $\sim 100$ and $380 \mu \mathrm{g} / \mathrm{ml}$, respectively (Fig. 2).

To investigate the effect of chronic exposure of endothelial cells to n-LDL on intracellular calcium, we incubated HCAEC

Table I. Effect of Long-Term (24-h) Preincubation with $n$-LDL on Cellular Calcium Levels

\begin{tabular}{lccc}
\hline & & PAEC & HCAEC \\
\hline Basal & & $53 \pm 1.0(104)$ & $75 \pm 6.5(95)$ \\
Control & PBS & $94 \pm 6.5(24)^{*}$ & $149 \pm 6.9(14)^{*}$ \\
LDL (24-h) & $500 \mu \mathrm{g} / \mathrm{ml}$ & $325 \pm 49(54)^{*}$ & $156 \pm 8.4(25)$ \\
& $700 \mu \mathrm{g} / \mathrm{ml}$ & $227 \pm 11(26)^{*}$ & $173 \pm 5.3(22)^{\ddagger}$
\end{tabular}

Addition of n-LDL ( $500 \mu \mathrm{g} / \mathrm{ml})$ to endothelial cells chronically exposed to $\mathrm{n}$-LDL (500 and $700 \mu \mathrm{g} / \mathrm{ml}$ ) for $24 \mathrm{~h}$ produces larger calcium rises compared with PBS-treated endothelial cells. Values represent mean \pm SEM and $n$ is total number of cells measured. Data were analyzed by ANOVA coupled with a Bonferroni correction. Bonferroni $P$ values are as follows: ${ }^{\ddagger} P<0.01$ control vs. $700 \mu \mathrm{g} / \mathrm{ml},{ }^{*} P<0.001$ control vs. basal and 500 and $700 \mu \mathrm{g} / \mathrm{ml}$. 
and PAEC for $24 \mathrm{~h}$ with n-LDL (500 and $700 \mu \mathrm{g} / \mathrm{ml}$ ) or with PBS. At the end of this incubation time we then measured the calcium rise after a further addition of $500 \mu \mathrm{g} / \mathrm{ml} \mathrm{n}-\mathrm{LDL}$. The results (Table I) show an increase in calcium levels after n-LDL challenge, in the endothelial cells preincubated for $24 \mathrm{~h}$ with n-LDL compared with controls (PBS preincubation).

Effect of minimally modified $L D L$ and oxidized $L D L$ on intracellular calcium. Because n-LDL is known to be oxidized by endothelial cells in vivo we also compared the effect of modified forms of $\mathrm{n}$-LDL on cell calcium levels. Minimally modified LDL $(100 \mu \mathrm{g} / \mathrm{ml}, n=40)$ had no apparent effect on intracellular calcium levels in HCAEC (data not shown). In contrast, oxidized LDL $(100 \mu \mathrm{g} / \mathrm{ml}, n=18)$ induced potent calcium rises in the HCAEC from a resting calcium level of $85 \pm 4$ to $465 \pm 67 \mathrm{nM}$.

Effect of VLDL and HDL on intracellular calcium. Since lipoprotein fractions in vivo are also made up of VLDL and HDL classes, we were also interested to know whether these two classes of lipoproteins could affect endothelial cell calcium levels. VLDL and HDL both induced a rise in intracellular calcium in PAEC from a resting level of $63 \pm 4$ to $183 \pm 22 \mathrm{nM}(100$ $\mu \mathrm{g} / \mathrm{ml} \mathrm{VLDL}, n=49)$ and $94 \pm 5$ to $388 \pm 72 \mathrm{nM}(500 \mu \mathrm{g} / \mathrm{ml}$ HDL, $n=41$ ), respectively.

Source of $n-L D L$-induced calcium changes. When HCAEC were bathed in a calcium-free external medium containing $1 \mathrm{mM}$ EGTA for 3-5 min, the basal calcium level was $84 \pm 3.4$ $\mathrm{nM}($ mean \pm SEM, $n=64)$. When stimulated with n-LDL (500 $\mu \mathrm{g} / \mathrm{ml}$ ) the calcium rose to $246 \pm 35 \mathrm{nM}$ (mean \pm SEM, $P<$ 0.001 unpaired $t$ test, $n=64)$, compared with $535 \pm 136 \mathrm{nM}$ (mean \pm SEM, $P<0.04$ n-LDL unpaired $t$ test, $n=15$ ) in cells bathed in calcium containing medium. Similarly, PAEC briefly exposed to bathing medium without calcium and with EGTA $(1 \mathrm{mM})$ had a basal calcium level of $54 \pm 1.2 \mathrm{nM}$ (mean \pm SEM, $n=87)$. Upon adding $\mathrm{n}-\mathrm{LDL}(500 \mu \mathrm{g} / \mathrm{ml})$ to cells bathed in calcium-free medium or to calcium-containing medium supplemented with cadmium chloride $(50 \mathrm{mM} ; 15$ min), to block entry of extracellular calcium, the calcium level rose to $105 \pm 20 \mathrm{nM}($ mean $\pm \mathrm{SEM}, P<0.01$ unpaired $t$ test, $n=$ 87 ) and $97 \pm 12 \mathrm{nM}$ (mean \pm SEM, $P<0.01$ unpaired $t$ test, $n=$ 87) respectively, compared with $255 \pm 46 \mathrm{nM}$ (mean \pm SEM, $P<0.01$ unpaired $t$ test, $n=120$ ) in control PAEC bathed in calcium-containing medium.

The ratio of the calcium rise in the absence and presence of
Table II. Anti-LDL Receptor Antibody (IgGC7) Attenuates $n$-LDL $(500 \mu \mathrm{g} / \mathrm{ml})$-induced Calcium Rises in HCAEC and $P A E C$

\begin{tabular}{lcc}
\hline & \multicolumn{2}{c}{$\mathrm{n}$-LDL $(500 \mu \mathrm{g} / \mathrm{ml})$-induced calcium levels $(\mathrm{nM})$} \\
\cline { 2 - 3 } & HCAEC & PAEC \\
\hline Basal calcium & $80 \pm 3(114)$ & $85 \pm 2(124)$ \\
Control & $600 \pm 70^{*}(27)$ & $260 \pm 35^{*}(26)$ \\
IgGC7 $5 \mu \mathrm{g} / \mathrm{ml}$ & $182 \pm 40^{*}(23)$ & $249 \pm 29(24)$ \\
IgGC7 $25 \mu \mathrm{g} / \mathrm{ml}$ & $178 \pm 35^{*}(24)$ & $252 \pm 20(26)$ \\
IgGC7 $50 \mu \mathrm{g} / \mathrm{ml}$ & $163 \pm 30^{*}(20)$ & $175 \pm 25^{\ddagger}(26)$ \\
IgG & $590 \pm 55(20)$ & $265 \pm 30(22)$ \\
& & \\
\hline
\end{tabular}

Increasing concentrations of the LDL receptor antibody IgGC7 inhibits the n-LDL $(500 \mu \mathrm{g} / \mathrm{ml})$-induced calcium rise in HCAEC and PAEC. Values represent mean \pm SEM and $n$ is total number of cells measured. Data were analyzed by ANOVA coupled with a Bonferroni correction. Bonferroni $P$ values are as follows: ${ }^{\ddagger} P<0.05$ control vs. IgGC7 $50 \mu \mathrm{g} /$ $\mathrm{ml}$ and $* P<0.001$ control vs. basal and $\mathrm{IgGC}$. IgG represents isotypematched control antibody.

external calcium was $\sim 44 \%$, suggesting a major contribution of extracellular calcium influx in the n-LDL-induced calcium rise in both cell types. To confirm the contribution of intracellular calcium stores in the n-LDL-induced calcium rise, the HCAEC and PAEC were pretreated with thapsigargin (10 $\mu \mathrm{g} / \mathrm{ml})$ in calcium-free external medium containing $1 \mathrm{mM}$ EGTA and in external medium containing calcium. Thapsigargin treatment caused an emptying of the internal calcium stores. Further addition of n-LDL $(500 \mu \mathrm{g} / \mathrm{ml})$ had no apparent effect on the intracellular calcium levels in either the HCAEC (Fig. 3) or PAEC (data not shown).

Nature of the $n$-LDL-induced calcium rise. To examine whether the $\mathrm{n}$-LDL-induced calcium rise is triggered by the specific LDL surface receptor (apo B/E receptor), we investigated the effect of $\mathrm{n}-\mathrm{LDL}(500 \mu \mathrm{g} / \mathrm{ml})$ on intracellular calcium transients $1 \mathrm{~h}$ after preincubation of HCAEC or PAEC with 5, 25 , or $50 \mu \mathrm{g} / \mathrm{ml}$ of the specific LDL receptor antibody IgGC7 (28) at $4^{\circ} \mathrm{C}$ or a control isotype IgG antibody. Cells were incubated at $4^{\circ} \mathrm{C}$ because the apparent affinity of the antibody for the $\mathrm{LDL}$ receptor is greater than at $37^{\circ} \mathrm{C}$. In $\mathrm{HCAEC}$, IgGC7

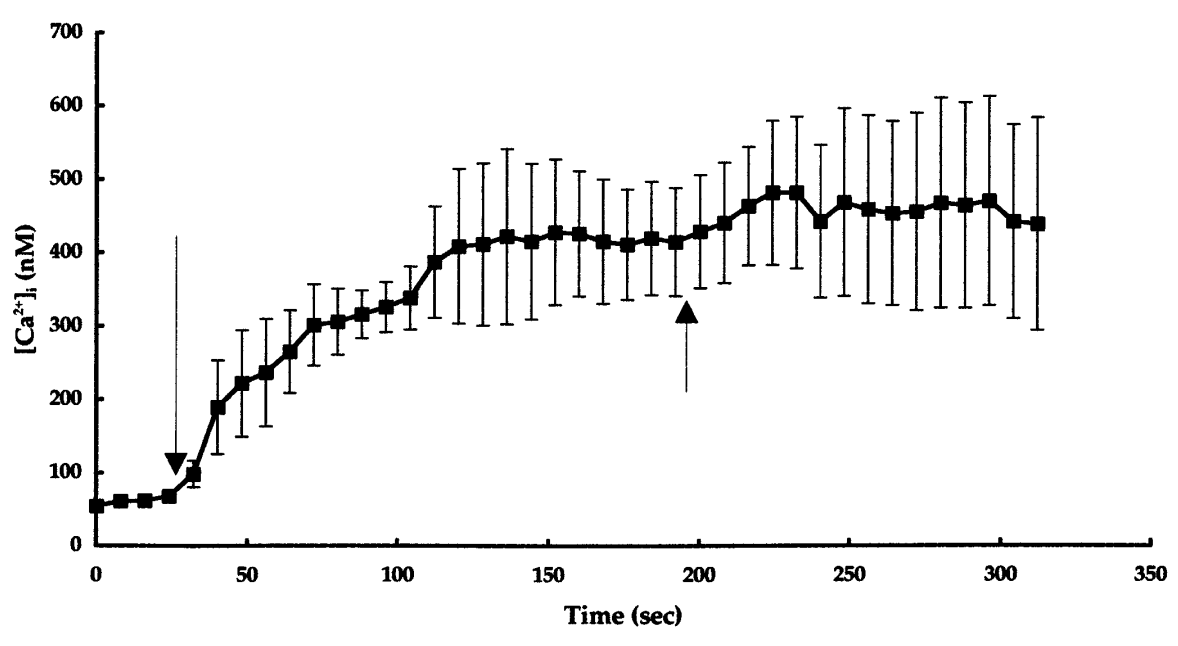

Figure 3. $\mathrm{n}-\mathrm{LDL}$ releases $\left[\mathrm{Ca}^{2+}\right]_{\mathrm{i}}$ from membrane-enclosed intracellular store. Emptying of the store by treatment of HCAEC with $10 \mu \mathrm{g} / \mathrm{ml}$ thapsigargin in the presence of extracellular calcium (left arrow). This treatment abolishes the n-LDLinduced calcium rise (right arrow). The values represent mean \pm SEM of 46 individual cells from three donor coronary arteries. 
blocked the n-LDL-induced calcium transients (Table II). However, in PAEC the effect of IgGC7 was less potent, attenuating the calcium transient only at the highest concentration of the antibody (Table II). The irrelevant IgG antibody had no apparent effect on n-LDL-induced calcium levels.

To confirm that the n-LDL-induced calcium rise is receptor mediated, we pretreated cells with pertussis toxin $(1 \mu \mathrm{g} / \mathrm{ml})$ for $1 \mathrm{~h}$ at $37^{\circ} \mathrm{C}$, a process that is known to inhibit receptor-mediated activation of phospholipase $\mathrm{C}$ and the subsequent influx and release of intracellular calcium. Pertussis toxin treatment, which had no apparent toxic effect as measured by trypan blue exclusion test, inhibited the n-LDL-induced calcium rise in both HCAEC and PAEC. Upon challenging HCAEC with n-LDL $(250 \mu \mathrm{g} / \mathrm{ml})$ the calcium rose from a resting level of $80 \pm 4$ to $150 \pm 6 \mathrm{nM}$ (mean \pm SEM, $P<0.001$ unpaired $t$ test, $n=15)$ in the absence of pertussis toxin to $83 \pm 15 \mathrm{nM}$ (mean \pm SEM, $n=75$ ) in the presence of pertussis toxin. Similarly, upon challenging PAEC with n-LDL $(500 \mu \mathrm{g} / \mathrm{ml})$, the calcium rose from a resting level of $54 \pm 1.2$ to $259 \pm 47 \mathrm{nM}$ (mean \pm SEM, $P<0.001$ unpaired $t$ test, $n=68$ ) in the absence of pertussis toxin to $57.4 \pm 1 \mathrm{nM}($ mean \pm SEM, $n=68)$ in the presence of pertussis toxin. These results suggest that the $\mathrm{n}$-LDL-induced calcium rise is mediated by LDL receptor coupling to heterotrimeric pertussis toxin-sensitive $G$ proteins.

Effect of protein kinase $C(P K C)$ inhibition on $n-L D L-$ induced calcium transients. The binding of n-LDL to the apo $\mathrm{B} / \mathrm{E}$ receptor leads to activation of $\mathrm{PKC}$ and subsequent downregulation of the LDL receptors $(29,30)$. Therefore we investigated what effect reversibly blocking the catalytic activity of PKC with H-7 $(31,32)(100 \mu \mathrm{M})$ would have on the n-LDL-induced calcium rise in PAEC. Although $\mathrm{H}-7$ is a relatively nonspecific PKC inhibitor, at $100 \mu \mathrm{M} \mathrm{H}-7$ blocked the intracellular calcium rise induced by thrombin and PMA (Fig. 4), two compounds known to act via PKC pathways $(33,34)$. These results suggested that H-7's effect as a PKC inhibitor in our cells was specific at this concentration and therefore this concentration was used to assess the role of PKC in n-LDL calcium signaling. Inhibition of PKC activation augmented the calcium rise after $\mathrm{n}-\mathrm{LDL}(500 \mu \mathrm{g} / \mathrm{ml})$ administration in $\mathrm{H}-7-$ treated cells (mean \pm
SEM, $n=78$, Fig. 4), suggesting the involvement of PKC in the regulation of $n-L D L-i n d u c e d$ calcium signaling via the LDL receptor in PAEC.

Indirect immunofluorescence of P-selectin expression on $P A E C$ stimulated with $L D L$. One of the earliest events in the activation of endothelial cells is the rapid redistribution of $\mathrm{P}$-selectin (CD62P) from Weibel-Palade bodies to the plasma membrane $(35,36)$. We found that in untreated PAEC the $\mathrm{P}$-selectin staining produced a punctate pattern (Fig. $5 \mathrm{~A}$ ) that typifies vesicle-containing $\mathrm{P}$-selectin in quiescent endothelial cells. The n-LDL treatment of PAEC produced a dramatically different pattern. There was diffuse staining over the entire cell surface, indicative of endothelial cell activation resulting in the translocation of P-selectin to the surface membranes of the endothelial cells (20) (Fig. 5 B). Similar staining patterns were observed with Br-ionophore-treated PAEC (Fig. $5 C$ ).

Flow cytometric analysis of E-selectin and VCAM-1 expression in endothelial cells stimulated with $n$ - $L D L$. Because adhesion molecules are expressed after activation of the endothelium, we investigated the possibility that the n-LDL-induced calcium rise might induce VCAM-1 expression in endothelial cells. In HCAEC there was a dose-dependent increase in VCAM-1 expression to n-LDL after $5 \mathrm{~h}$ (Fig. 6). The maximum change in adhesion molecule expression occurred with $500 \mu \mathrm{g} / \mathrm{ml} \mathrm{n}-\mathrm{LDL}$ and was $14.7 \pm 1.2 \%$ of the mean TNF- $\alpha-$ induced VCAM-1 response which was $90 \pm 5 \%$. By $12 \mathrm{~h}$ the levels of VCAM-1 had declined (data not shown). The expression of VCAM-1 was inhibited in the HCAEC that were preloaded with the intracellular calcium chelator BAPTA/AM before $n$-LDL treatment, indicating $n$-LDL-induced calcium transients were triggering the expression of VCAM-1. To determine whether the effect of $n$-LDL on VCAM-1 expression was specific for this surface adhesion molecule, we also measured the effect of n-LDL on E-selectin expression. In HCAEC n-LDL $(500 \mu \mathrm{g} / \mathrm{ml})$ induced a small, but nonsignificant increase in E-selectin expression after $5 \mathrm{~h}$ (basal $0.67 \pm 0.3$ to $4.1 \pm 1.7 \%, P=$ NS with ANOVA, $n=5$ experiments performed in duplicate).

To determine whether the effect of n-LDL on VCAM-1 and E-selectin expression could be induced on other vascular

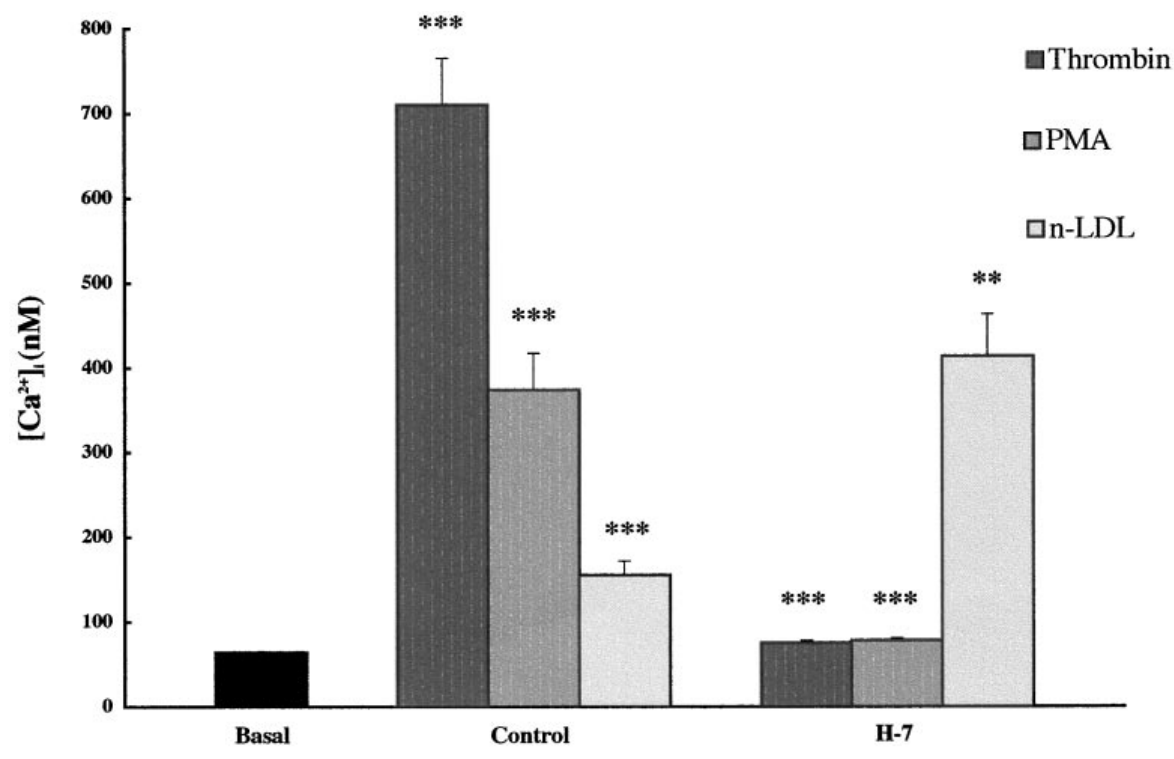

Figure 4. Bar graphs showing effect of PKC inhibition with $\mathrm{H}-7$ on n-LDLinduced $\left[\mathrm{Ca}^{2+}\right]_{\mathrm{i}}$. PAEC were preincubated for $30 \mathrm{~min}$ at $37^{\circ} \mathrm{C}$ with $\mathrm{H}-7(100 \mu \mathrm{M})$. PAEC were then loaded with Fura-2/AM as indicated in Methods. Agonists were then added, in the continued presence of the inhibitor. The values represent mean \pm SEM of five separate experiments performed on a total of 60 individual cells. Statistics were performed using ANOVA incorporating repeated measures coupled with a post-hoc Bonferroni correction. Bonferroni $P$ values are as follows: $* * P<$ $0.002 ; * * * P<0.001$ controls vs. H-7. 


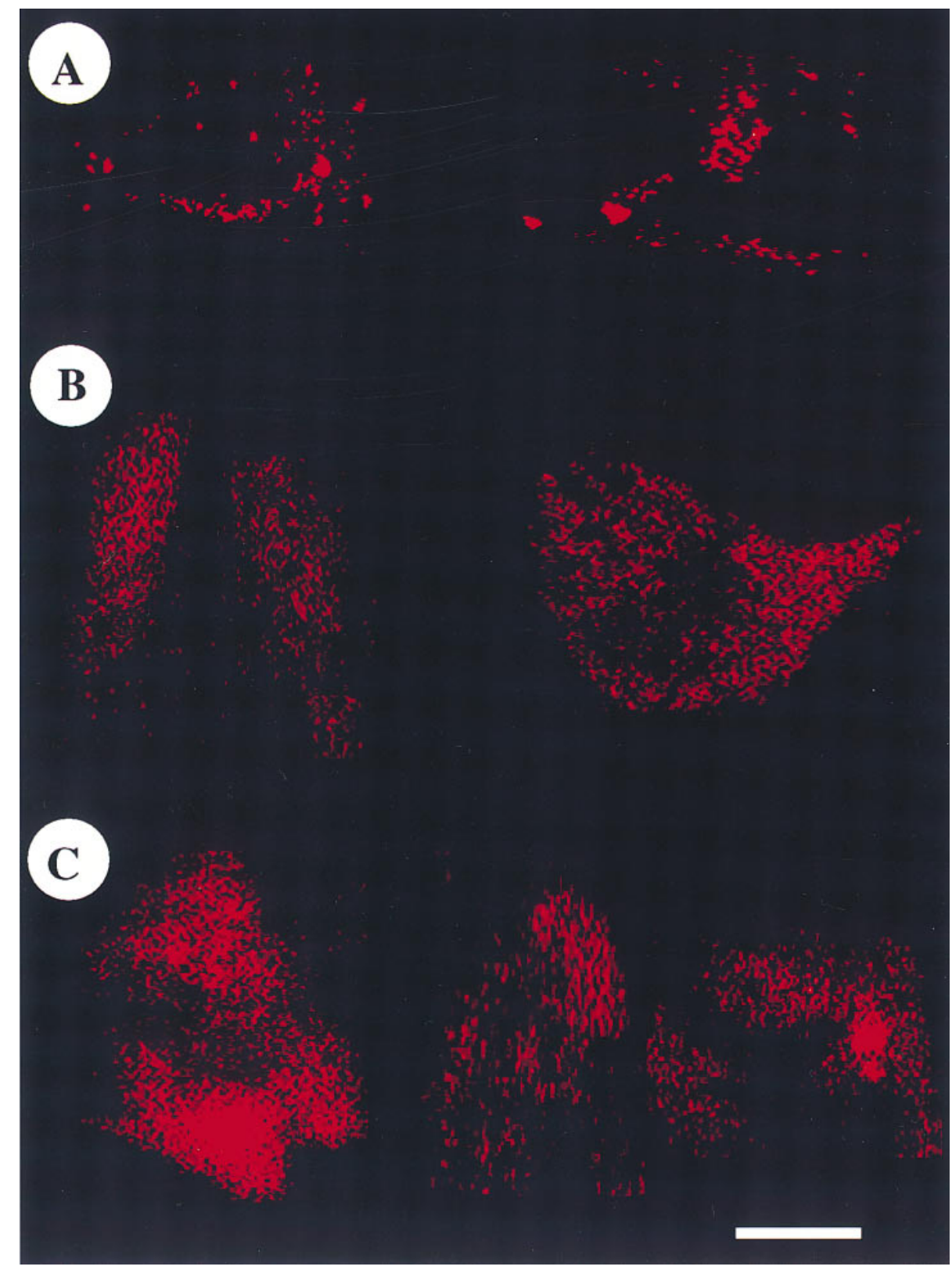

Figure 5. Activation of PAEC by n-LDL. Fluorescent confocal micrographs of immunolabeled P-selectin in PAEC before $(A), 5 \mathrm{~min}$ after exposure to $\mathrm{n}-\mathrm{LDL}$ $(500 \mu \mathrm{g} / \mathrm{ml})(B)$, and after exposure to $\operatorname{Br}-\mathrm{A} 23187(2 \mu \mathrm{M})(C)$. Scale bar $=10 \mu \mathrm{m}$. $\mathrm{P}$-selectin was visualized by indirect immunofluorescence using a monoclonal anti-P-selectin antibody (CD62/ GMP140, clone AC1.2) and TRITCconjugated secondary antibody (Pierce). Cells were viewed with a laser-scanning confocal microscope (Noran Instruments). The fluorescent micrograph is representative of six individual experiments. endothelial cells we repeated the experiments in HAEC and PAEC. Preincubation of increasing concentrations of $n-L D L$ for $5 \mathrm{~h}$ induced expression on the endothelial cell surface of both VCAM-1 (Table III) and E-selectin in HAEC (Fig. 7). The maximum change in E-selectin expression occurred with $500 \mu \mathrm{g} / \mathrm{ml} \mathrm{n}-\mathrm{LDL}$ and was $12.0 \pm 4 \%$ of the mean TNF- $\alpha$ response which was $95 \pm 5 \%$. In PAEC, 5 -h n-LDL pretreatment also induced surface expression of VCAM-1 (Table III), while the expression of E-selectin was not affected by exposure to n-LDL (data not shown). The expression of VCAM-1 and E-selectin in HAEC and VCAM-1 in PAEC was also inhibited in the endothelial cells that were preloaded with BAPTA/AM before $n$-LDL treatment, indicating that n-LDL-induced calcium transients were required for adhesion molecule expression. Furthermore, in both the human and porcine endothelial cells the maximum change in adhesion molecule expression and the largest rise in intracellular calcium levels were both produced by the same concentration of n-LDL $(500 \mu \mathrm{g} / \mathrm{ml})$.

Endothelial cells preincubated with TPEN responded to $\mathrm{n}$-LDL by expressing similar increases in adhesion molecule expression (data not shown), thus ensuring that the inhibitory effect of BAPTA/AM is caused strictly by the ability of BAPTA/AM to buffer calcium and is not scavenging other biochemically important metal ions. In addition, experiments which included BHT added to the n-LDL showed no significant differences in the amount of adhesion molecule expression compared with those experiments that did not incorporate $\mathrm{BHT}$ into the $\mathrm{n}-\mathrm{LDL}$ (data not shown). These findings argue against the oxidation/modification of $n-L D L$ in our cell culture model, suggesting that the adhesion molecule expression induced in the endothelial cells was likely to be due to unmodified n-LDL. 


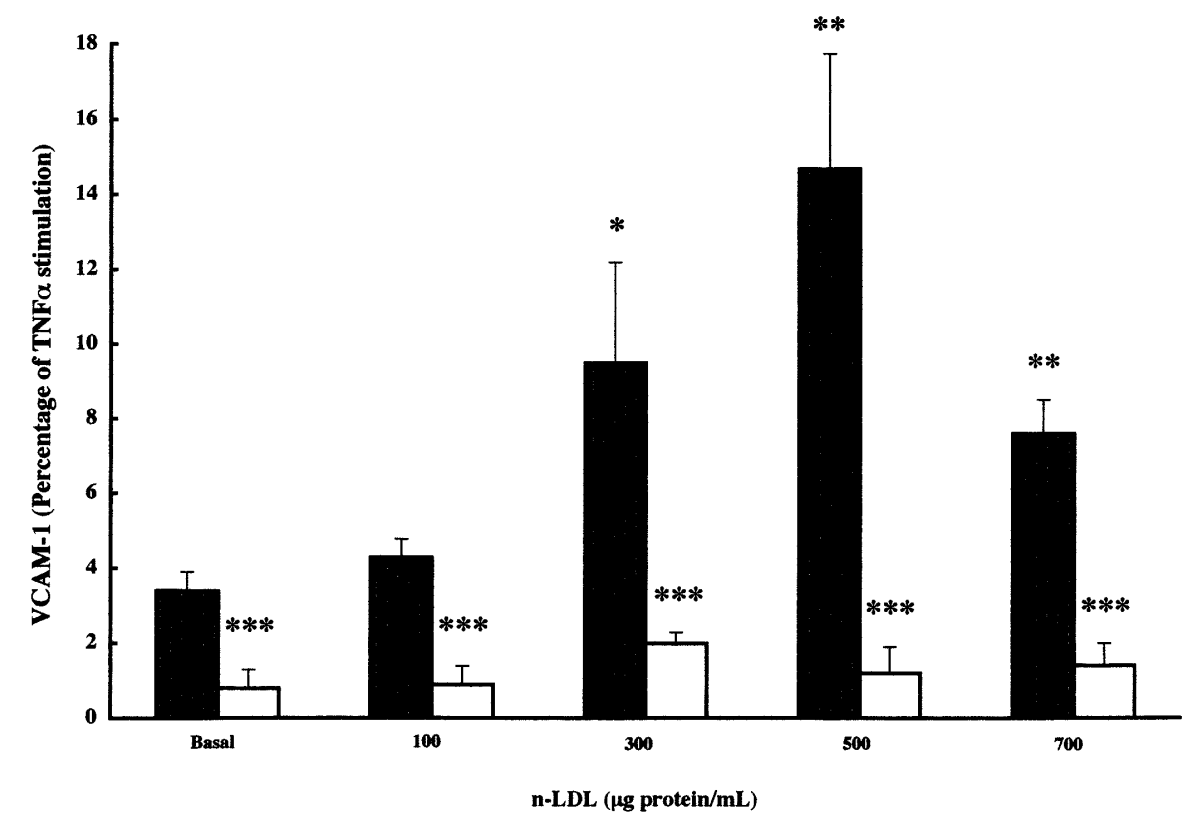

Figure 6. Bar graph shows VCAM-1 surface expression on HCAEC induced by increasing concentrations of $\mathrm{n}-\mathrm{LDL}$ and expressed as a percentage of the TNF- $\alpha$ response (black bars). The HCAEC were preincubated with either TNF- $\alpha(10 \mathrm{ng} / \mathrm{ml})$ or increasing concentrations of n-LDL $(100-700 \mu \mathrm{g} / \mathrm{ml})$ for $5 \mathrm{~h}$ before assaying for VCAM-1. Some cells were pretreated with BAPTA/AM (10 $\mu \mathrm{M}$ for $30 \mathrm{~min})$ before n-LDL was added (white bars). Results are represented as mean \pm SEM of five separate experiments performed in duplicate from three donor coronary arteries. Statistics were performed using repeated measures ANOVA. The $P$ values are as follows: $* P<0.04, * * P<0.004$, and $* * * P<$ 0.001 .

Binding of human monocytes to HCAEC. Human monocytes bind to HCAEC treated with n-LDL $(500 \mu \mathrm{g} / \mathrm{ml}, 5 \mathrm{~h}$ at $\left.37^{\circ} \mathrm{C}\right)$ more avidly (175 \pm 11 monocytes) than HCAEC untreated (93 \pm 6 monocytes) (Fig. 8). This binding was inhibited by chelating the intracellular calcium with BAPTA/AM (101土 10 monocytes) or by a monoclonal antibody to VCAM-1 (88 \pm 5 monocytes) on the endothelial membranes (Fig. 8). An irrelevant $\mathrm{IgG}$ isoform had no apparent effect on this binding (data not shown).

\section{Discussion}

In this study we demonstrate the novel finding that n-LDL binding to the LDL receptor can trigger intraendothelial cell calcium transients which act as a second messenger to induce expression of VCAM-1 and minimal amounts of E-selectin in human vascular endothelial cells and VCAM-1 in porcine vascular endothelial cells. The increase in VCAM-1 by n-LDL results in increased monocyte binding to HCAEC which can be attenuated by inhibiting the intracellular calcium rise or blocking the VCAM-1 binding sites. These results link calcium signaling conferred by n-LDL to mechanisms controlling the expression of endothelial cell adhesion molecules implicated in atherosclerosis.

LDL interaction with monocytes and coronary artery endothelial cells seems to be one of a number of factors critical to development of atherosclerosis. The mechanism(s) behind this effect is not fully understood, although several lines of evidence support the idea that oxidation of LDL increases its atherogenicity. Much less is known about the mechanism(s) by which n-LDL activates endothelial cells to influence atherogenesis. Several studies have shown that LDLs can produce a rise in endothelial cell calcium, whereas other studies have shown induction of adhesion molecules on the surface of the endothelial cells, which in some cases augment monocyte binding. It is not known whether LDL-induced calcium transients are a link between levels of circulating LDL and adhesion molecule expression on endothelial cells.
In this work, we demonstrate that n-LDL binding to the LDL receptor induces a rise in intracellular calcium which signals the cells to induce both selectin and immunoglobulin superfamily member expression in three separate endothelial cell lines. The major source of the n-LDL-dependent calcium rise in the endothelial cells is the release from intracellular membrane store(s). This was confirmed by the lack of calcium fluxes in thapsigargin-treated or pertussis toxin-treated HCAEC and PAEC. Influx of calcium from the extracellular medium contributed $\sim 40 \%$ of the n-LDL-induced intracellular calcium rise. This influx was demonstrated by the attenuation of the calcium signal in endothelial cells bathed in medium with extracellular calcium removed and EGTA present and by

Table III. VCAM-1 Expression on HAEC and PAEC Induced by Increasing Concentrations of $n-L D L$

\begin{tabular}{cccccc}
\hline & \multicolumn{2}{c}{ HAEC } & & \multicolumn{2}{c}{ PAEC } \\
\cline { 2 - 3 } \cline { 5 - 6 } LDL $(\mu \mathrm{g} / \mathrm{ml})$ & VCAM-1 & BAPTA/AM & & VCAM-1 & BAPTA/AM \\
\hline 0 & $0.9 \%$ & $0.5 \%$ & & $40 \%$ & $24 \%$ \\
100 & $4 \%$ & $2 \%$ & & $58 \%$ & $14.3 \%$ \\
300 & $6 \%$ & $2.5 \%$ & & $62 \%$ & $11.6 \%$ \\
500 & $11 \%$ & $3 \%$ & & $75 \%$ & $21 \%$ \\
700 & $12 \%$ & $3 \%$ & & $52 \%$ & $35 \%$ \\
\hline
\end{tabular}

Concentration-dependent increases in VCAM-1 expression on HAEC and PAEC by n-LDL. In HAEC the VCAM- 1 is measured as the number of positive cells while in the PAEC VCAM-1 is measured as the mean fluorescence intensity to account for the high basal VCAM-1 levels found in PAEC. All values are expressed as a percentage of the TNF- $\alpha$ response. The HAEC and PAEC were preincubated with either TNF- $\alpha(10 \mathrm{ng} / \mathrm{ml})$ or $\mathrm{n}-\mathrm{LDL}(100-700 \mu \mathrm{g} / \mathrm{ml})$ for $5 \mathrm{~h}$ before assaying for VCAM-1. Some cells were pretreated with BAPTA/AM $(10 \mu \mathrm{M}, 30$ min) before $n-L D L$ was added. The results are representative of four HAEC experiments performed in duplicate from three donor aortae and four PAEC experiments performed in duplicate from four pig aortae. 


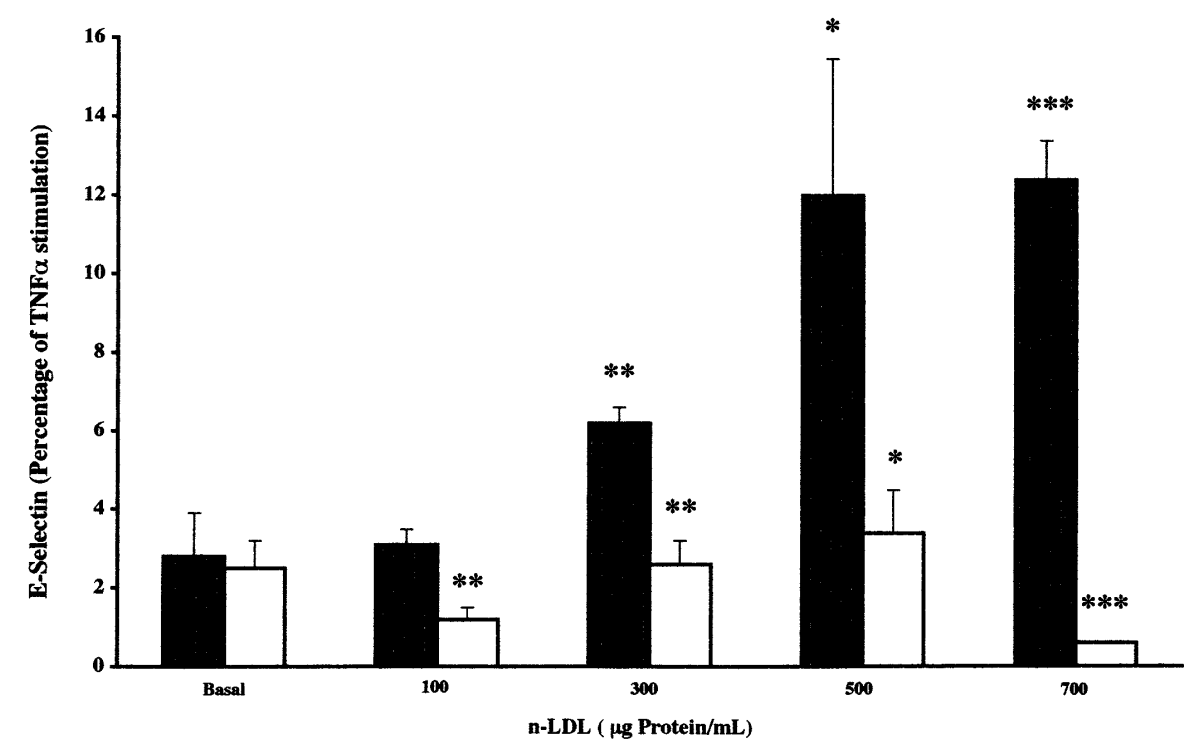

Figure 7. Bar graph shows E-selectin surface expression on HAEC induced by increasing concentrations of n-LDL and expressed as a percentage of the TNF- $\alpha$ response (black bars). The HAEC were preincubated with either TNF- $\alpha(10 \mathrm{ng} / \mathrm{ml})$ or increasing concentrations of n-LDL $(100-700 \mu \mathrm{g} / \mathrm{ml})$ for $5 \mathrm{~h}$ before assaying for E-selectin. Some cells were pretreated with BAPTA/AM (10 $\mu \mathrm{M}$ for $30 \mathrm{~min})$ before $\mathrm{n}$-LDL was added (white bars). Results are represented as mean \pm SEM of four separate experiments performed in duplicate from three donor coronary arteries. Statistics were performed using repeated measures ANOVA. $P$ values are as follows $* P<0.04, * * P<0.01$, and $* * * P<0.001$. incubation of cells with cadmium chloride to block influx through calcium channels. By depleting the intracellular calcium stores with thapsigargin we completely prevented the $\mathrm{n}$-LDL-induced calcium transient. The LDL-induced calcium rise is transient, probably due to a rapid regulation by the intracellular calcium homeostatic mechanisms. Long-term incubations of HCAEC and PAEC with n-LDL ( $24 \mathrm{~h})$ revealed that the calcium regulation is altered, resulting in higher levels of intracellular calcium induced by n-LDL (Table I).

Similarly, smooth muscle cells incubated for 1-3 d with high levels of LDL responded with significantly faster calcium exchange kinetics in both the intracellular and extracellular compartments (37). If calcium homeostasis is important in atherogenesis, then it is tempting to speculate that chronic exposure of vascular cells to n-LDL could alter calcium regulation mechanisms that favor an accumulation of calcium within endothelial cells and smooth muscle cells similar to that observed in atherosclerotic vessels. Indeed, recent evidence suggests that high levels of lipoproteins may influence the degree of calcium within the vessel wall. Using ultrafast computed tomography, the amount of calcium within atherosclerotic coronary vessels correlated significantly with the patient's dyslipoproteinemia (38). These findings further highlight the potential relationship between lipoprotein-induced calcium signaling and coronary artery disease.

To define the molecular recognition site where n-LDL is binding, we performed experiments in the presence of an antibody to the classical LDL receptor. Preincubation of HCAEC and PAEC with monoclonal antibodies (IgGC7) against specific surface LDL receptors attenuated or abolished the $\mathrm{n}$-LDL-induced calcium rise with increasing concentrations of the antibody. These results indicate that the action of n-LDL appears to be mediated by binding to the LDL receptor. The binding of LDL to a number of cell types, including platelets (39), vascular smooth muscle cells and fibroblasts $(40,41)$, and endothelial cells (16) is known to trigger cellular events which lead to activation of phospholipase $\mathrm{C}$ and the subsequent production of inositol 1,4,5-triphosphate $\left(\mathrm{IP}_{3}\right)$ and diacylglycerol

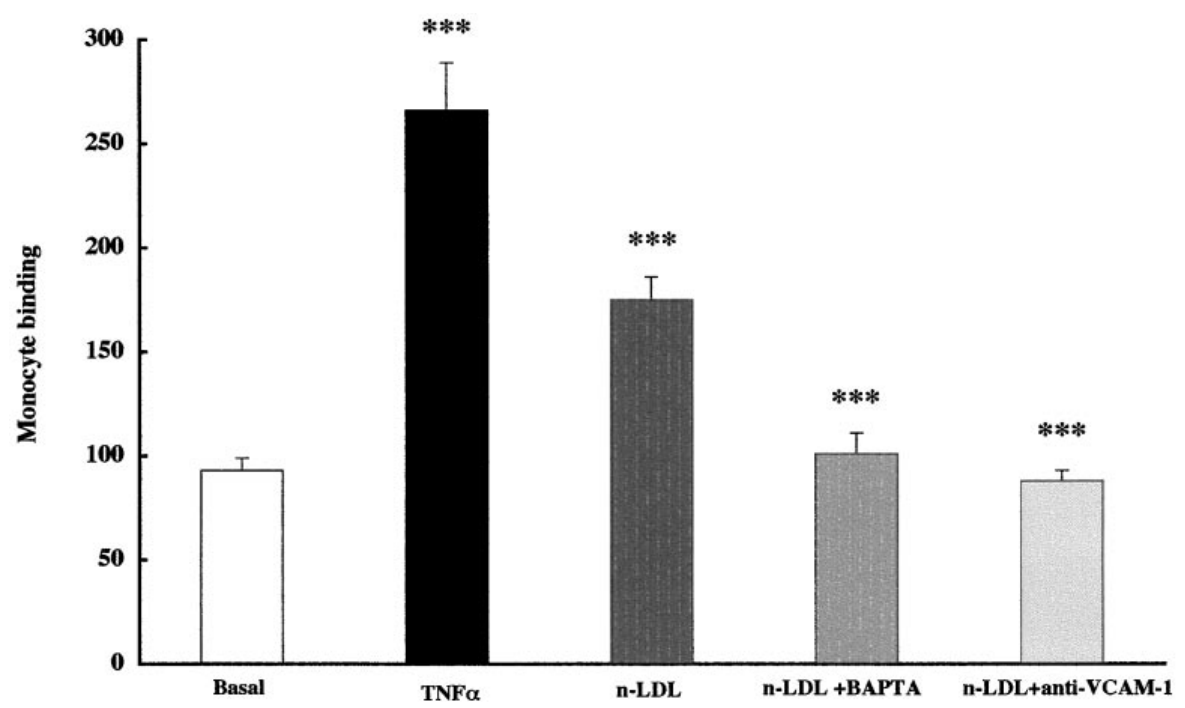

Figure 8. Bar graph shows monocyte binding to control (TNF- $\alpha, 10 \mathrm{ng} / \mathrm{ml})$ and n-LDL-treated $(500 \mu \mathrm{g} / \mathrm{ml})$ HCAEC. Results are expressed as number of monocytes bound per triplicate well and are mean $\pm \operatorname{SEM}(n=3)$. BAPTA/AM (to block the intracellular calcium rise) and anti-VCAM-1 antibody (to block surface VCAM-1 molecules) both significantly attenuated the binding of monocytes to n-LDL-treated HCAEC. Statistics were performed using ANOVA incorporating repeated measures coupled with a post-hoc Bonferroni correction. Bonferroni $P$ values are as follows: $* * * P<0.001$ for basal vs. TNF- $\alpha$ and n-LDL and n-LDL vs. n-LDL + BAPTA and n-LDL + anti-VCAM-1. 
(DAG). $\mathrm{IP}_{3}$ causes release of intracellular calcium and DAG activates PKC $(42,43)$. The activation of PKC is known to cause desensitization of LDL receptors $(29,30)$. Furthermore, LDL elevates intracellular calcium in platelets and this effect is completely blocked after activation of PKC (44). We show that inhibition of PKC with H-7 in PAEC augments the n-LDLinduced calcium rise, suggesting that LDL receptor-mediated calcium transients may be regulated by PKC. Whether the potentiation of the calcium rise is related to preventing desensitization of the LDL receptors by $\mathrm{PKC}$ or to the known inhibitory actions of H-7 on cAMP and c-GMP-dependent kinases (45) remains to be determined.

Oxidized LDL, but not minimally modified LDL, was also able to induce calcium rises in HCAEC. Furthermore, our preliminary investigations with two other classes of lipoproteins, VLDL and HDL, have shown that they also induce a calcium rise in PAEC. HDL is well known to be capable of activating second-messenger systems coupled to elevation of intracellular calcium $(46,47)$. Whether HDL is binding to an HDL receptor, such as the recently described SR-BI scavenger receptor, or to the LDL receptor via apo E binding to induce these signals is not known at present.

Very little is known about the effect of VLDL on intracellular calcium. There appears to be only one study to date that shows that VLDL can induce alterations in vascular smooth muscle cell calcium exchange kinetics (37). It is possible that VLDL-induced calcium transients are due to an interaction with the LDL receptor via apo E binding. Alternatively, VLDL could possibly be interacting with a VLDL receptor on pig endothelial cells to induce these changes. Additional work is necessary to clarify the molecular signaling mechanisms by which these modified LDL molecules and different lipoprotein classes activate endothelial cells and to identify the functionality of such a calcium rise.

Calcium is the most common signal transduction element in cells which results in activation of the cell when the concentration of calcium changes. One of the earliest events in the activation of endothelial cells is the rapid redistribution of P-selectin (CD62P) from Weibel-Palade bodies to the plasma membrane $(35,36)$. In a recent study, Murohara et al. (48) showed that lysophosphatidylcholine, which is a major phospholipid component in oxidized LDL, promotes P-selectin expression in endothelial cells. We show here that n-LDL can also elicit rapid P-selectin surface expression on PAEC which could also be induced by the calcium Br-ionophore. This translocation of P-selectin occurred within 5 min of n-LDL treatment and was dependent on a rise in intracellular calcium. New evidence suggests that P-selectin may play an important role in the initiation of atherosclerosis. P-selectin expression was shown to precede accumulation of macrophages and $\mathrm{T}$ lymphocytes into the intima of hypercholesterolemic rabbits (49) while another study showed that P-selectin is significantly unregulated on the endothelium, which facilitates leukocyte rolling on the microvascular endothelium during mild hypercholesterolemia in rats (50). Furthermore, monocyte/macrophage recruitment to chronic inflammatory sites is significantly attenuated in P-selectin-deficient mice (51).

Monocyte recruitment into blood vessels and tissues occurs via binding to intracellular adhesion molecule-1 and VCAM-1 on the endothelium, via the beta 2 integrins and very late antigen 4 receptors, respectively (52). Animals fed hypercholesterolemic diets exhibit increases in monocytic cell binding to the endothelium after $7 \mathrm{~d}$ (53). After only $1 \mathrm{wk}$ on atherogenic diets, rabbits exhibit focal increases in VCAM-1 before the first appearance of intimal macrophages (11). In this regard, we investigated the possibility that the n-LDL-induced calcium rise might induce VCAM-1 expression and increase monocyte binding in endothelial cells. Exposure of HCAEC, HAEC, and PAEC to n-LDL induced expression of VCAM-1 on the surface membranes.

Induced VCAM-1 protein was inhibited in both the human and the pig endothelial cells that were pretreated with the intracellular calcium chelator BAPTA/AM before n-LDL exposure. Treatment of HCAEC with n-LDL also increased monocyte binding which could be attenuated by preventing the increase in calcium with BAPTA/AM or blocking the VCAM-1 binding sites with an anti-VCAM-1 antibody. These results indicate that $n$-LDL-induced intracellular calcium transients in endothelial cells are required for the induction of VCAM-1 and increased monocyte binding.

There has been a lot of debate concerning the ability of $\mathrm{n}$-LDL to induce adhesion molecules in cultured endothelial cells. Some studies have shown induction of adhesion molecules with n-LDL $(26,54)$, while other groups failed to show any effect of n-LDL (55). These discrepancies are not explained easily, but may depend on the endothelial cell line used as well as the source and concentration of LDL and incubation conditions. Our results showed that there was no difference in the ability of n-LDL to induce adhesion molecule expression when it was protected from mild oxidation by BHT. These data argue against the oxidation/modification of $n$-LDL in our cell culture model suggesting that the adhesion molecule expression induced in the endothelial cells was likely to be due to unmodified n-LDL.

Despite revealing that $n-L D L$ can induce calcium transients in endothelial cells in vitro, a fundamental question remains: How do the calcium transients observed when endothelial cells are exposed to abrupt changes in lipoprotein concentration relate, physiologically, to the rather less abrupt changes that occur in steady-state levels of plasma n-LDL in vivo? Since the in vitro concentrations of n-LDL used in this study to elicit a cellular response are comparable to those found in vivo (56), then it is possible that the calcium mobilizing systems of endothelial cells in vivo maybe subject to permanent regulatory control by lipoproteins. In other words, steady-state levels of n-LDL may be sufficient to produce calcium changes within the endothelial cells. On the other hand, the concentration of n-LDL in the milieu of the endothelial cell may be the crucial element that results in cellular activation. The concentration of n-LDL in the region of the LDL receptor may well fluctuate from the plasma concentration due to the continued recycling of the LDL receptor, its interaction with LDL-related receptors, and its possible interaction with different lipoprotein classes, remnants, and other molecules. Also, the heterogeneity of particle size of LDL could also be a factor which could contribute to the activation of the endothelial cells in vivo. Whatever the case may be, the answer to this question is complex since calcium can have a multiplicity of effects, involving processes that contribute additional positive or negative feedback to local and global calcium release. The precise balance between local negative and positive feedback determines whether the calcium transients will advance to induce a cellular response (such as adhesion molecule production) or decline. 
To date, the specific role of any leukocyte adhesion molecule in human atherogenesis remains unproven. However, pathological specimens and measurements of soluble adhesion molecules in vivo are beginning to provide data suggesting a possible interaction between adhesion molecules and atherosclerosis. Immunohistochemical studies of normal human aortic and coronary arteries without lesions reveal no staining of E-selectin or VCAM-1 (57), or weak staining of VCAM-1 $(58,59)$. However, specimens with intimal thickening express higher E-selectin $(57)$ and VCAM-1 $(58,59)$ levels in the endothelium of the coronary arteries. In addition, in a recent study patients with hypercholesterolemia were associated with increased levels of soluble intracellular adhesion molecule-1, VCAM-1, and E-selectin compared with control subjects, which the authors say may be a marker for atherosclerosis (60). Thus, in humans one of the earliest changes in the adhesive properties of the vessel wall in early lesion development may be increased E-selectin and VCAM-1 resulting from the interaction of lipoproteins with the vascular endothelium.

In conclusion, our study shows that intracellular calcium transients play a critical role in the activation mechanisms by which n-LDL results in increased selectin and integrin production in endothelial cells resulting in increased monocyte binding. It is hoped that these findings may help in understanding the role of lipoproteins and calcium in human atherogenesis.

\section{Acknowledgments}

We would like to thank Professor A. Lusis for his critical reading of the manuscript and to Professor D. Haskard for the kind gift of the pig VCAM-1 and E-selectin antibodies. We would also like to thank Dr. Dilip Patel (MRC Lipoprotein Group, Hammersmith Hospital), Dr. Richard Siow (Vascular Biology Research Centre, King's College) and Dr. David Leake (School of Animal and Microbial Sciences, University of Reading) for their kind gifts of fresh n-LDL and modified LDL, respectively.

\section{References}

1. Steinberg, D., and J.L. Witztum. 1990. Lipoproteins and atherogenesis: current concepts. JAMA (J. Am. Med. Assoc.). 264:3047-3052.

2. Scandinavian Simvastatin Survival Group. 1994. Randomised trial of cholesterol lowering in 4444 patients with coronary heart disease: the Scandinavian Simvastatin Survival Study. Lancet. 344:1383-1389.

3. Shepherd, J., S. Cobbe, I. Ford, C.G. Isles, A.R. Lorimer, P.W. Macfarlane, and J.H. McKillop. 1995. Prevention of coronary heart disease with pravastatin in men with hypercholesterolemia. N. Engl. J. Med. 333:1301-1307.

4. Faruqi, R.M., and P.E. DiCorleto. 1993. Mechanisms of monocyte recruitment and accumulation. Br. Heart. J. 69:S19-S29.

5. Parthasarathy, S., D. Steinberg, and J.L. Witztum. 1992. The role of oxidized low-density lipoprotein in the pathogenesis of atherosclerosis. Annu. Rev. Med. 43:219-225.

6. Yla-Herttuala, S., M.E. Rosenfeld, S. Parthasarathy, E. Sigal, T. Sarkioja, J.L. Witztum, and D. Steinberg. 1991. Gene expression in macrophage-rich human atherosclerotic lesions. 15-lipoxygenase and acetyl LDL receptor mRNA colocalize with oxidation specific lipid-protein adducts. J. Clin. Invest. 87:11461152 .

7. Brown, M.S., S.K. Basu, J.R. Falck, Y.K. Ho, and J.L. Goldstein. 1980. The scavenger cell pathway for lipoprotein degradation: specificity of binding site that mediate the uptake of negatively charged LDL by macrophages. J. Supramol. Struct. 13:67-81.

8. McEver, R.P. 1992. Leukocyte-endothelial interactions. Curr. Opin. Cell. Biol. 4:840-849.

9. Murohara, T., R. Scalia, and A.M. Lefer. 1996. Lysophosphatidylcholine promotes P-selectin expression in platelets and endothelial cells: possible involvement of protein kinase $\mathrm{C}$ activation and its inhibition by nitric oxide donors. Circ. Res. 78:780-789.

10. Mehta, A., B. Yang, S. Khan, J.B. Hendricks, C. Stephen, and J.L. Mehta. 1995. Oxidized low-density lipoproteins facilitate leukocyte adhesion to aortic intima without affecting endothelium-dependent relaxation: role of P-selectin. Arterioscler. Thromb. Vasc. Biol. 15:2076-2083.

11. Li, H., M.I. Cybulsky, M.A. Gimbrone, Jr., and P.A. Libby. 1993. An atherogenic diet rapidly induces VCAM-1, a cytokine regulatable mononuclear leukocyte adhesion molecule, in rabbit aortic endothelial cells. Arterioscler Thromb. Vasc. Biol. 13:197-204.

12. Cushing, S.D., J.A. Berliner, A.J. Valente, M.C. Territo, M. Navab, F. Parhami, R. Gerrity, C.J. Schwartz, and A.M. Fogelman. 1990. Minimally modified LDL induces monocyte chemotactic protein 1 in human endothelial and smooth muscle cells. Proc. Nat. Acad. Sci. USA. 87:5134-5138.

13. Rajavashisth, T.B., A. Andalibi, M.C. Territo, J.A. Berliner, M. Navab, A.M. Fogelman, and A.J. Lusis. 1990. Induction of endothelial cell expression of granulocyte and macrophage colony-stimulating factors by modified lowdensity lipoproteins. Nature. 344:254-257.

14. Strickberger, S.A., L.N. Russek, and R.D. Phair. 1988. Evidence for increased aortic plasma membrane calcium transport caused by experimental atherosclerosis in rabbit. Circ. Res. 62:75-80.

15. Henry, P.D., and K.I. Bentley. 1981. Suppression of atherogenesis in cholesterol-fed rabbits treated with nifedipine. J. Clin. Invest. 68:1366-1369.

16. Smirnov, V.N., T.A. Voyno-Yasenetskaya, A.S. Antonov, M.E. Lukashev, V.P. Shirinsky, T.T. Tertov, and V.A. Tkachuk. 1990. Vascular signal transduction and atherosclerosis. Ann. NY Acad. Sci. 598:167-181.

17. Negre-Salvaryre, A., G. Fitoussi, V. Reaud, M.T. Pieraggi, J.C. Thiers, and R. Salvayre. 1992. A delayed and sustained rise of cytosolic calcium is elic ited by oxidised low-density lipoprotein in cultured bovine aortic endothelial cells. FEBS Lett. 299:60-65.

18. Schaefer, H.I.M.P., K.M. Hold, J.M. Egas-Kenniphaas, and A. van der Laarse. 1993. Intracellular calcium signaling after binding of low-density lipoprotein to confluent and non-confluent cultures of an endothelial cell line, EA.hy926. Cell. Calcium. 14:507-516.

19. Phair, R.D. 1988. Cellular calcium and atherosclerosis. Cell. Calcium. 9 : 275-284.

20. Al-Mohanna, F.A.A., K.S. Collison, R.S. Parhar, A.A. Kwaasi, B. Meyer, S. Saleh, S. Allen, S.T. Al-Sedairy, D. Stern, and M. Yacoub. 1997. Activation of naive xenogeneic but not allogeneic endothelial cells by human naive neutrophils: a potential occult barrier to xenotransplantation. Am. J. Pathol. 151:111-120.

21. Batten, P., M.H. Yacoub, and M.L. Rose. 1995. Effect of human cytokines (IFN- $\gamma$, TNF- $\alpha$, IL-1 $\beta$, IL-4) on porcine endothelial cells: induction of MHC and adhesion molecules and functional significance of these changes. Immunology. 87:127-133.

22. Rudel, L.L., J.A. Lee, M.D. Morris, and J.M. Felts. 1974. Characterization of plasma lipoprotein separated and purified by agarose-column chromatography. Biochem. J. 139:89-95.

23. Rubenstein, B., S. Evans, and G. Steiner. 1977. A new method for the fractionation of human plasma high density lipoprotein. Can. J. Biochem. 55: 766-768.

24. Collison, K.S., A.A. Kwaasi, R.S. Parhar, S.T. Al-Sedairy, and F.A.A. Al-Mohanna. 1995. Monomeric human IgE evokes a transient calcium rise in individual human neutrophils. J. Leuk. Biol. 58:459-467.

25. Pritchard, K.A., Jr., R.R. Tota, J. Lin, K.J. Danishefsky, B.A. Kurilla, J.A. Holland, and M.B. Stemerman. 1991. Native low-density lipoprotein: endothelial cell recruitment of mononuclear cells. Arterioscler. Thromb. 11:11751181 .

26. Smalley, D.M., J.H.C. Lin, M.L. Curtis, Y. Kobari, M.B. Stemerman, and K.A. Pritchard, Jr. 1996. Native LDL increases endothelial cell adhesiveness by inducing intercellular adhesion molecule-1. Arterioscler. Thromb. Vasc. Biol. 16:585-590.

27. Marlor, M., D.L. Webb, M.P. Bombara, J.M. Greve, and M.L. Blue. 1992. Expression of vascular cell adhesion molecule-1 in fibroblast synoviocytes after stimulation with tumor necrosis factor. Am. J. Pathol. 140:1055-1060.

28. Beisiegel, U., W.J. Schneider, J.L. Goldstein, R.G.W. Anderson, and M.S. Brown. 1981. Monoclonal antibodies to the low density lipoprotein receptor as probes for study of receptor-mediated endocytosis and the genetics of familial hypercholesterolemia. J. Biol. Chem. 256:11923-11931.

29. Morita, R., S. Morimoto, E. Koh, F. Keisuke, K. Shouei, I. Kazuyuki, T. Kazuhisa, O. Toshio, and O. Toshio. 1989. Low-density lipoprotein and apo protein $\mathrm{B}$ induce increases in inositol triphosphate and cytosolic free calcium via pertussis toxin sensitive GTP-binding protein in vascular smooth muscle cells. Biochem. Int. 18:647-653.

30. Kiss, Z. 1990. Effects of phorbol esters on phospholipid metabolism. Prog. Lipid. Res. 29:141-166.

31. Wolf, M., H. Levine III, W.S. May, Jr., P. Cuatrecasas, and N. Sahyoun. 1985. Role of intracellular calcium mobilization in the regulation of protein kinase C-mediated membrane processes. Nature. 317:549-551.

32. Parker, P.J., L. Coussens, N. Totty, L. Rhee, S. Young, E. Chen, S. Stabel, M.D. Waterfield, and A. Ullrich. 1986. The complete primary structure of protein kinase C: the major phorbol ester. Science. 233:853-859.

33. Lynch, J.J.L., T.J. Ferro, F.A. Blumenstock, A.M. Brockenauer, and A.B. Malik. 1990. Increased endothelial albumin permeability mediated by protein kinase C activation. J. Clin. Invest. 85:1991-1998.

34. Lum, H., P.J. Del Vecchio, A.S. Schneider, M.S. Goligorsky, and A.B. 
Malik. 1989. Calcium-dependence of the thrombin-induced increase in endothelial albumin permeability. J. Appl. Physiol. 66:1471-1476.

35. McEver, R.P. 1991. Properties of GMP-140, an inducible granule membrane protein of platelets and endothelium. J. Cell. Biochem. 45:156-161.

36. Zimmerman, G.A., S.M. Prescott, and T.M. McIntyre. 1992. Endothelial cell interactions with granulocytes: tethering and signaling molecules. Immunol. Today. 13:93-99.

37. Kutryk, M.J.B., and G.N. Pierce. 1991. Effects of low-density lipoprotein on calcium ion movements in cultured vascular smooth muscle cells. Coronary. Art. Dis. 2:1093-1101.

38. Barbir, M., F. Lazem, T. Bowker, P. Ludman, N. Banner, A. Mitchell, and M. Yacoub. 1997. Determinants of transplant-related coronary calcium detected by ultrafast computed tomography scanning. Am. J. Cardiol. 79:16061609.

39. Block, L.H., M. Knorr, E. Vogt, R. Locher, W. Vetter, P. Groscurth, B.Y. Qiao, D. Pometta, R. James, M. Regenass, and A. Pletscher. 1988. Lowdensity lipoprotein causes general cellular activation with increased phosphatidylinositol turnover and lipoprotein catabolism. Proc. Natl. Acad. Sci. USA. 85: 885-889.

40. Scott-Burden, T., T.A.J. Resink, A.W.A. Hahn, U. Baur, R.J. Box, and F.R. Buhler. 1989. Induction of growth-related metabolism in human vascular smooth muscle cells by low-density lipoprotein. J. Biol. Chem. 264:1258212589

41. Sachindis, A., R. Locher, T. Mengden, and W. Vetter. 1990. Low-density lipoprotein elevates intracellular calcium and $\mathrm{pH}$ in vascular smooth muscle cells and fibroblasts without mediation of the LDL receptor. Biochem. Biophys. Res. Commun. 167:353-359.

42. Streb, H., R.F. Irvine, M.J. Berridge, and I. Schulz. 1983. Release of calcium from an non-mitochondrial store in pancreatic acina cells by $\mathrm{IP}_{3}$. Nature. 306:67-69.

43. Locher, R., A. Sachinidis, A. Steiner, and W. Vetter. 1990. Attenuation of the low-density-lipoprotein-activated phosphoinositide signaling system by calcium blockers in human lymphocytes. Clin. Sci. 78:509-514.

44. Avdonin, P.V., I.B. Cheglakov, E.M. Boogry, I.V. Svitina-Ulitina, A.V. Mazaev, and V.N. Tkachuk. 1987. Evidence for the receptor-operated calcium channels in human platelet plasma membrane. Thromb. Res. 46:29-37.

45. Ho, A.K., C.L. Chik, and D.C. Klein. 1988. Effects of protein kinase inhibitor (1-(5-isoquinolinesulfonyl)-2-methylpiperazin) (H-7) on protein kinase $\mathrm{C}$ activity and adrenergic-stimulation of cAMP and cGMP in rat pinealocytes. Biochem. Pharmacol. 37:1015-1020.

46. Bochkov, V.N., V.A. Tkachuk, F.R. Buhler, and T.J. Resink. 1992. Phosphoinositide and calcium signaling responses in smooth muscle cells: comparison between lipoproteins, Ang II and PDGF. Biochem. Biophys. Res. Commun. 188:1295-1304.

47. Bochkov, V.N., V.A. Tkachuk, Y.S. Kuzmenko, Y.L. Borisova, F.R. Buh- ler, and T.J. Resink. 1994. Characteristics of low and high density lipoprotein binding and lipoprotein-induced signaling in quiescent human vascular smooth muscle cells. Mol. Pharmacol. 45:262-270.

48. Murohara, M., R. Scalia, and A.M. Lefer. 1996. Lysophosphatidylcholine promotes P-selectin expression in platelets and endothelial cells. Possible involvement of protein kinase $\mathrm{C}$ activation and its inhibition by nitric oxide donors. Circ. Res. 78:780-789.

49. Sakai, A., N. Kume, H. Ochi, E. Nishi, H. Moriwaki, K. Tanoue, and T. Kita. 1995. P-selectin and VCAM-1 are focally expressed in hypercholesterolemic rabbits before intimal accumulation of macrophages and Tymphocytes. Circulation. 92(Suppl. 1):I558-I559. (Abstr.)

50. Gauthier, T.W., R. Scalia, T. Murohara, J.P. Guo, and A.M. Lefer. 1995 Nitric oxide protects against leukocyte-endothelial interaction of early hypercholesterolemia. Arterioscler. Thromb. Vasc. Biol. 15:1652-1659.

51. Johnson, R.C., T.N. Mayadas, P.S. Frenette, R.E. Mebius, M. Subramaniam, A. Lacasce, R.O. Hynes, and D.D. Wagner. 1995. Blood cell dynamics in P-selectin-deficient mice. Blood. 86:1106-1114.

52. Cybalsky, M.I., and M.A. Gimbrone, Jr. 1991. Endothelial expression of a mononuclear leukocyte adhesion molecule during atherogenesis. Science. 251: 788-791.

53. Rosenfeld, M.E., T. Tsukada, A.M. Gown, and R. Ross. 1987. Fattystreak initiation in Watanabe heritable hyperlipidemic and comparably hypercholesterolemic fat-fed rabbits. Arteriosclerosis. 7:9-23.

54. Haller, H., D. Schaper, W. Ziegler, S. Philipp, M. Kuhlmann, A. Distler, and F.C. Luft. 1995. Low-density lipoprotein induces vascular adhesion molecule expression on human endothelial cells. Hypertension. 25:511-516.

55. Kume, N., M.I. Cybulsky, and M.A. Gimbrone, Jr. 1992. Lysophosphatidylcholine, a component of atherogenic lipoproteins, induces mononuclear leukocyte adhesion molecules in cultured human and rabbit arterial endothelial cells. J. Clin. Invest. 90:1138-1144.

56. Bochkov, V.N., V.A. Tkachuk, A.W.A. Hahn, J. Bernhardt, F.R. Buhler, and T.J. Resink. 1993. Concerted effects of lipoproteins and angiotensin II on vascular smooth muscle cells. Arterioscler. Thromb. 13:1261-1269.

57. Wood, K.M., M.D. Cadogan, A.L. Ramshaw, and D.V. Parums. 1993. The distribution of adhesion molecules in human atherosclerosis. Histopathology. 22:437-444.

58. Taylor, P.M., M.L. Rose, and M.H. Yacoub. 1993. Coronary artery immunogenicity: a comparison between explanted recipient or donor hearts and transplanted hearts. Transplant. Immunol. 1:294-301.

59. Page, C., M.L. Rose, and M.H. Yacoub. 1992. Antigeneic heterogeneity of vascular endothelium. Am. J. Pathol. 141:673-683.

60. Hackman, A., Y. Abe, W. Insull, Jr., H. Pownall, L. Smith, K. Dunn, A.M. Gotto, Jr., and C.M. Ballantyne. 1996. Levels of soluble cell adhesion molecules in patients with dyslipidemia. Circulation. 93:1334-1338. 